\title{
未破裂脳動脈瘤症例の治療と転帰
}

\author{
木 村 雅 人, 吉 永 真 也, 田中彰
}

\section{Treatment and Outcome of the Unruptured Cerebral Aneurysms}

Masato Kimura, M.D., Shinya Yoshinaga, M.D., and Akira TanaKa, M.D.

Department of Neurosurgery, Fukuoka University, Chikushi Hospital, Fukuoka, Japan

Summary : Treatment and outcome of 41 patients with unruptured cerebral aneurysms (11 males, 30 females, 23-74 years, 53 years on average) were evaluated. They were discovered in 24 patients with subarachnoid hemorrhage due to a rupture of the other aneurysm, in 13 patients with neurological deficits and in 4 patients with headache (screening of organic lesions). Surgery was not performed on 7 patients or patients with severe subarachnoid hemorrhage. Two of 4 patients with intradural aneurysms developed a subarachnoid hemorrhage and had a poor outcome, whereas all 3 patients with extradural aneurysms had a good outcome. Surgery was performed on 26 patients. Twenty patients with aneurysm of less than $15 \mathrm{~mm}$ diameter underwent direct surgery and all had a good outcome. Four patients with aneurysm larger than $15 \mathrm{~mm}$ diameter underwent direct surgery and 3 had a poor outcome, whereas 2 patients who underwent a trapping with a balloon had a good outcome. From these findings, it is concluded that direct surgery should be done for an unruptured cerebral aneurysm less than $15 \mathrm{~mm}$ diameter, but an embolization should be chosen at first for larger aneurysm. Direct surgery, if it is performed, requires cautions and through preparations pre- and intra-operatively.

\section{はじめに}

脳動脈瘤治療の理想は, それを破裂前に発見し適切な処 置をすることである. しかし現段階では難しく，いったん 破裂すると約 $50 \%$ が死亡あるいは社会復帰不可能となり， 予後不良の疾患である. そこで, もし未破裂の状態で発見 されたならば，それをいかに処置をするかが問題となる. 今回我々は, 未破裂脳動脈瘤 41 症例を経験し, その治療 と転帚を検討した。

\section{対象}

対象は，1986〜1990 年までに入院した，未破裂脳動脈 瘤 41 症例で, 男性 11 例, 女性 30 例, 年齢は 23〜74 歳,
Key words :

- unruptured aneurysm

- surgery

- embolization

福岡大学筑紫病院 脳神経外科(受稿日 1991.7.3)〔連絡先： T817-01 筑紫野市大字俗明院 377-1 福岡大学筑紫病院 脳神経外科 田中 彰] 
Table 1 Location of unruptured cerebral aneurysms

\begin{tabular}{|l|c|c|}
\hline 動脈瘤部位 & 動脈瘤数（個) & 症例数（例） \\
\hline 内頸動脈 & 28 & 24 \\
前交通执び & 4 & 4 \\
前大脑動脈 & & 9 \\
中大胹動脈 & 11 & 4 \\
椎骨-脳底動脈 & 4 & \\
\hline
\end{tabular}

Table 2 Size of unruptured cerebral aneurysms

\begin{tabular}{|c|c|}
\hline 動脈瘤の大きさ & 動脈瘤数（個） \\
\hline $5 \mathrm{~mm}$ 未満 & 3 \\
$5 \mathrm{~mm} \sim 15 \mathrm{~mm}$ & 33 \\
$15 \mathrm{~mm} \sim 25 \mathrm{~mm}$ & 1 \\
$25 \mathrm{~mm}$ 以上 & 10 \\
\hline
\end{tabular}

Table 3 Causes of discovery of unruptured cerebral aneurysms

\begin{tabular}{|l|c|}
\hline \multicolumn{1}{|c|}{ 動脈瘤発見の誘因 } & 症例数 (例) \\
\hline 破裂脳動脈瘤との共存 & 24 \\
神 経 症 状 & 13 \\
頭痛に拈けるスクリーニング & 4 \\
\hline
\end{tabular}

Table 4 Causes of non-surgery of unruptured cerebral aneurysms

\begin{tabular}{|l|c|}
\hline 手術回避の理由 & 症例数 (例) \\
\hline 重篤クモ膜下出血 & 8 \\
手術困難 & 4 \\
高 齢 & 2 \\
本人拒否 & 1 \\
\hline
\end{tabular}

\section{1 例であった(Table 4).}

重篤クモ膜下出血発症例を除く手術回避例 7 例の転帰は 硬膜内の動脈瘤では，大きさにかかわらず 4 例中 2 例が破 裂しており 1 例は不良， 1 例は死亡した。一方，硬膜外の 動脈瘤は，すべて $15 \mathrm{~mm}$ 以上の大きさで転帰良好であっ た (Table 5).

残り 26 例に外科的治療を行った。 26 例の治療の内訳は 直達手術が 24 例，balloonによる trapping 術が 2 例であ った。直達手術では, 動脈瘤を clipping し, trapping 術で は動脈瘤の遠位部と近位部で親動脈を detachable balloon を用いて閉塞した。この 26 例を脳動脈瘤の大きさで 2 群 に分けそれぞれについて転州を検討した。最大径 $15 \mathrm{~mm}$ 未満の未破裂脳動脈瘤症例は 20 例で全例に直達手術を行 418 脳卒中の外科 $20: 1992$
Table 5 Prognosis of non-surgical cases of unruptured cerebral aneurysms (cases of subarachnoid hemorrhage by a rupture of the other aneurysm, excluded)

\begin{tabular}{|c|c|c|c|c|}
\hline \multirow{2}{*}{ 動脈瘤部位 } & \multirow{2}{*}{ 動脈瘤の大きさ } & \multicolumn{3}{|c|}{ 予 後 } \\
\cline { 3 - 6 } & & 良 & 不 良 & 死 亡 \\
\hline \multirow{2}{*}{ 硬 膜 内 } & $15 \mathrm{~mm}$ 以上 & 1 & $1 \%$ & 0 \\
\cline { 3 - 6 } 硬 膜 外 & $15 \mathrm{~mm}$ 未満 & 1 & 0 & $1 \%$ \\
\cline { 3 - 6 } & $15 \mathrm{~mm}$ 以上 & 3 & 0 & 0 \\
\hline
\end{tabular}

※動脈瘤破裂

Table 6 Prognosis of surgical cases of unruptured cerebral aneurysms

\begin{tabular}{|c|c|c|c|c|}
\hline \multirow{2}{*}{ 治療方法 } & \multirow{2}{*}{ 動脈瘤の大きさ } & \multicolumn{3}{|c|}{ 予 後 } \\
\cline { 3 - 5 } & & 良 & 不 良 & 死 亡 \\
\hline \multirow{2}{*}{ 直達手術 } & $15 \mathrm{~mm}$ 以上 & 1 & 2 & 1 \\
\cline { 3 - 6 } & $15 \mathrm{~mm}$ 未満 & 20 & 0 & 0 \\
\hline \multirow{2}{*}{ トラッピング術 } & $15 \mathrm{~mm}$ 以上 & 2 & 0 & 0 \\
\cline { 2 - 5 } & $15 \mathrm{~mm}$ 未満 & 0 & 0 & 0 \\
\hline
\end{tabular}

った。この転帰はすべて良好であった。最大径 $15 \mathrm{~mm}$ 以 上の large, giant の未破裂脳動脈瘤症例は 6 例で, このう ち2 例は共に年齢が若く, 動眼および三叉神経障害にて発 症し症状が進行性であった。CT所見では非血栓型で，血 管造影では内頸動脈に動脈瘤を認め, Matas test 後, trapping 術を行い転帰は良好であった。他の 4 例には直達手 術を施行したが，1例が死亡し，2 例は転帰不良となった (Table 6). その 2 症例は頭痛に扔けるスクリーニングで 発見された患者である. 症例 1 は，65 歳の内頸動脈巨大 動脈瘤の患者で, clippingにより親動脈の狭窄をきたし片 麻痺を残した。症例 2 は, 66 歳の中大脳動脈巨大動脈瘤 の患者で wide neckのため clipping 時に近くの穿通枝 (レ ンズ核線条体動脈)を巻き込み，片麻痺を残した。以下に, 死亡例を呈示する (Fig. 1).

症例は 62 歳, 女性. truncal ataxiaにて発症. 入院時レ ベルは, alertであった. Fig. 1 の CTでは, 小脳中心部に 丸く淡い high densityの mass が均一に造影された. 血管 造影では, 左椎骨動脈の後下小脳動脈分岐部より末端で巨 大脳動脈瘤を認めた。脳底動脈は右椎骨動脈より灌流を受 け左椎骨動脈掞よび脳動脈瘤とは, 交通がないと考えたた め, 左椎骨動脈を動脈瘤の近くで clipping した。術後 CT で動脈瘤は縮小し, 術後経過は順調であったが, 4 日目突 然死亡した，その原因として，動脈瘤内に形成された血栓 


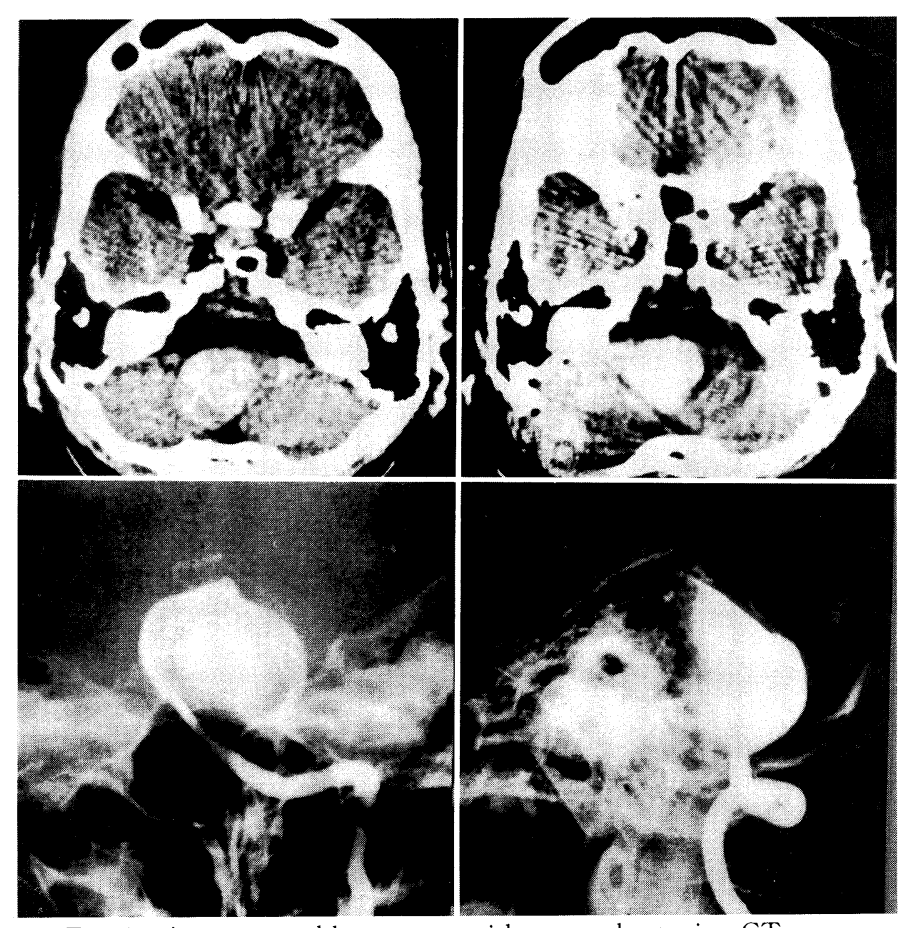

Fig. 1 A 62-year-old woman with truncal ataxia. CT scan disclosed a round enhanced mass in the mid portion of the cerebellum (upper left) and cerebral angiography demonstrated a giant aneurysm in the junction of vertebral and posterior inferior cerebellar artery on the left side (lower rows). The vertebral artery was clipped near the aneurysm and shrinkage of the aneurysm was confirmed on CT scan (upper right). She died suddenly 4 days after surgery, probably due to embolism of the thrombus inside the aneurysm into the basilar artery.

が脳底動脈系に飛んだものと考えた。

\section{考案}

未破裂脳動脈瘤の発見率は, 神経放射線学的検査の発達 により, 今後増加すると考えられるが, その治療法の決定 は，その自然経過と比較して行われるべきである。今まで の報告では，年間 2 ～ $5 \%$ の破裂を認めたといい(4)7), 浅 利ら ${ }^{1)}$ やHeiskanen ら ${ }^{3)}$ は, 経過中 10〜 12\%が破裂したと 報告している．また致死的破裂率は $2 \sim 7 \%$ とされ(1)3), 破裂した未破裂脳動脈瘤の約 $50 \%$ が死亡していることに なる。我々の症例では, クモ膜下出血発症例を除いた手術 回避例は 7 例であった。硬膜内動脈瘤 4 例のうち 2 例では その後クモ膜下出血を起こして転帰不良であった。しかし 硬膜外動脈瘤の 3 例はすべて転州良好であった。 宮城ら ${ }^{6)}$ も, 内頸動脈一海綿静脈洞部の動脈瘤は破裂することはほ とんどなく，外科的処置を行わなくとも転帰は良いと報告 しており，これと一致する．次に，未破裂脳動脈瘤に対す る手術適応やその成績を左右する因子として, 動脈瘤の大 きさがある。浅利ら ${ }^{1)}$ は， $4 \mathrm{~mm}$ 以上の大きさになると破
裂する危険があるので手術の適応があるとし，福井ら ${ }^{2)} や$ Jomin ら) $^{5)}$, $10 \mathrm{~mm}$ 以下の大きさであれば手術成績は良 好であるとの報告をしている，我々の症例では， $15 \mathrm{~mm}$ 未満の動脈瘤の手術成績は，20 例全例で良好であった。

しかし $15 \mathrm{~mm}$ 以上の動脈瘤の手術成績は，6 例中直達手 術を施行した 4 例では，1例のみが良好であったにすぎな かったが， balloonによる trapping 術を行った他の 2 例は 良好であった。このような内頸動脈や椎骨動脈の動脈瘤に 対しては，術前に十分な cross circulation が確認されてい れば, balloonによる親動脈の trapping 術も治療法の一つ にあげられる。しかし，動脈瘤そのものを balloonで閉塞 するには，その位置や neck の大きさなどが問題となり必 ずしも容易ではない，一方，直達手術をするとしても，一 時血行を遮断し動脈瘤切開, 血栓除去, 複数のクリップを 用いた clipping 術など複雑かつ高度な手術操作が必要と なる．術前の詳細な脳循環動態の把握と術中モニタリング を含めた周到な術中対策が不可欠な所以である. 


$$
\text { まと め }
$$

1) $15 \mathrm{~mm}$ 未満の未破裂脳動脈瘤には直達手術を行うべ きである

2）15 mm 以上の未破裂脳動脈瘤には balloonによる動脈 瘤自体か親動脈の閉塞術がまず検討され，直達手術を 行う場合には詳細かつ周到な術前術中の対策が必要で ある。

\section{文献}

1）浅利正二，山本祐司：未破裂脳動脈瘤一-80 例の臨床的検討 と新しい分類について一，脳と神経 38: 693-700, 1986

2）福井啓二, 古田 茂, 榊 三郎，ほか：未破裂脳動脈瘤に 対する手術成績. 脳卒中 12: 271-277, 1990
3) Heiskanen O: Risks of surgery for unruptured intracranial aneurysms. J Neurosurg 65: 451-453, 1986

4) Jane JA, Winn HR, Richardson AE: The natural history of intracranial aneurysms; Rebleeding rates during the acute and long term period and implication for surgical manage. ment. Clin Neurosurg 24: 176-189, 1977

5) Jomin M, Lesion G, Lozed G, et al: Surgical prognosis of unruptured intracranial arterial aneurysms. Report of 50 cases. Acta Neurochir (Wien) 84: 85-88, 1987

6）宮城 潤, 重森 稔, 李 宗一, ほか：直達手術困難な頭 蓋内巨大内䅡動脈瘤症例 $の$ 長期予後. 脳神経外科 15 : 1257-1253, 1987

7) Winn HR, Almaani WS, Berga SL, et al: The long-term outcome in patients with multiple aneurysms. Incidence of late hemorrhage and implication for treatment of incidental aneurysms. J Neurosurg 59: 642-651, 1983 